\title{
Etika Ritual Hindu di Bali Menghadapi Masa Pandemi
}

\author{
Ayu Veronika Somawati ${ }^{1}$, Ni Made Yunitha Asri Diantary ${ }^{2}$ \\ STAHN Mpu Kuturan Singaraja ${ }^{12}$ \\ 1ayuvero90@gmail.com, ${ }^{2}$ yunitha27@gmail.com
}

\author{
Riwayat Jurnal \\ Artikel diterima: 6 Maret 2021 \\ Artikel direvisi: 5 Juni 2021 \\ Artikel disetujui: 23 Juni 2021
}

\begin{tabular}{l|l} 
Kata Kunci: & Abstrak
\end{tabular}

Etika

Secara teologis, umat Hindu memiliki tiga kerangka dasar yang

Ritual

Hindu di Bali

Pandemi dijadikan pedoman dalam menjalankan kehidupan beragama. Tattwa yang sebagai substansi filosofi setiap aktivitas dan simbol; susila yang menjadi keutamaan penunjang yang memegang peranan penting bagi tata kehidupan manusia sehari-hari; serta acara yang di dalamnya termasuk aktivitas ritual, yang mengimplementasikan nilai-nilai tattwa dan susila dalam wujud tata keberagamaan yang lebih riil dalam dimensi kebudayaan. Aktivitas ritual atau perbuatan sacral yang dilaksanakan oleh umat Hindu merupakan sebuah ekspresi dari pemaknaan yajna atau korban suci yang tulus ikhlas. Ritual agama Hindu tersebut dapat dilakukan setiap hari maupun hari pada hari suci tertentu, yang merupakan wujud rasa syukur dan bhakti umat Hindu kehadapan Tuhan Yang Mahaesa. Tanpa adanya acara, agama hanyalah seperangkat ajaran yang tidak akan nampak dalam dunia fenomenal. Semenjak masa pandemic covid-19 hingga saat ini, pemerintah mengeluarkan kebijakan "new normal". Hal ini menyangkut banyak aspek kehidupan masyarakat, tidak terkecuali pada bidang keagamaan. Segala aktivitas keagamaan khususnya yang dilaksanakan oleh masyarakat Hindu Bali, mengalami keterbatasan. Perubahan perilaku sosial dalam pelaksanaan ritual ini mengalami sebuah revolusi yang dapat dilihat yang jika diamati lebih cermat, masyarakat saat ini lebih mendahulukan etika keamanan namun tidak mengurangi makna dari ritual yang dilaksanakan, sehingga pelaksanaan aktivitas keagamaan tidak terkubur dalam aktivitas di masa pandemi.

\section{Keyword:}

Ethics

\section{Abstract}

Theologically, Hindus have three basic frameworks that serve as Rituals guidelines in carrying out their religious life. Tattwa which is the philosophical substance of every activity and symbol; morality 


\begin{tabular}{|l|l|}
\hline Hinduism in Bali & $\begin{array}{l}\text { which is a supporting virtue which plays an important role in the } \\
\text { order of everyday human life; as well as acara which include } \\
\text { ritual activities, which implement tattwa and moral values in the } \\
\text { form of a more real religious system in the cultural dimension. } \\
\text { Ritual activities or sacred actions carried out by Hindus are an } \\
\text { expression of the meaning of the yajna or holy sacrifices that are } \\
\text { sincere. The Hindu religious ritual can be performed every day or } \\
\text { on certain holy days, which is a form of gratitude and devotion to } \\
\text { the Lord Almighty by Hindus. Without an event, religion is just a } \\
\text { set of teachings that will not appear in the phenomenal world. } \\
\text { Since the Covid-19 pandemic until now, the government has issued } \\
\text { a "new normal" policy. This concerns many aspects of community } \\
\text { life, including in the religious field. All religious activities, } \\
\text { especially those carried out by the Balinese Hindu community, are } \\
\text { limited. Changes in social behavior in the implementation of } \\
\text { religious rituals have experienced a revolution that can be seen } \\
\text { that if we observe more closely, today's society prioritizes security } \\
\text { ethics but does not reduce the meaning of rituals, so that the } \\
\text { implementation of religious activities is not buried in activities in } \\
\text { the pandemic period. }\end{array}$ \\
\hline
\end{tabular}

\section{Pendahuluan}

Perilaku manusia menjadi tolak ukur dalam memberikan kesan dalam kehidupannya serta setiap aktivitas dan perilaku sehari-hari merupakan ciri dan identitas sebagai manusia yang memiliki jati diri. Setidaknya setiap perilaku yang dilakukan umat manusia diharapkan adanya peningkatan ke arah yang postif atau lebih baik, namum pada kenyataannya perilaku ini selalu berdampingan antara baik dan buruk. Sebuah keyakinan dan bhakti umat manusia khususnya umat Hindu wajib untuk ditingkatkan, sehingga dapat menumbuhkan nilai dharma atau kebenaran dalam kehidupannya di masyarakat. Itulah mengapa setiap umat manusia penting memiliki pengetahuan spiritual sebagai dasar mengejar dharma tersebut. Ajaran agama Hindu menekankan pentingnya karakter moral dalam pengejaran pengetahuan spiritual, karena spiritual bukan sekedar bersifat kesarjanaan, tetapi merupakan keberadaan dan pertumbuhan. Pengetahuan spiritual itu tidak akan muncul dalam pikiran manusia jika moralnya tidak murni, sebuah keyakinan atau sraddha penting untuk dipupuk oleh setiap umat manusia.

Setiap individu memiliki tingkat keyakinannya dan evolusi spiritual yang berbedabeda, karena perkembangan kesadaran dari masing-masing pribadi itu tidak sama persis, tergantung pada faktor penentu yang mempengaruhinya baik itu secara langsung maupun tidak langsung. Maswisnara (1996:41) di dalam bukunya menjelaskan bahwa dengan memahami 
Satya Widya : Jurnal Studi Agama Vol. 4 No. 12021

P-ISSN : 2623-0534

E-ISSN : 2655-1454

Website Jurnal : https://ejournal.iahntp.ac.id/index.php/satya-widya/index

DOI: https://doi.org/10.33363/swjsa.v\%vi\%i.672

dasar sraddha sebagai landasan kepercayaan, maka cakrawala pandang dari masing-masing pribadi akan bertambah luas, sebagaimana halnya dengan luasnya ajaran Veda yang sifatnya kekal dan abadi itu. Untuk itu, sebagai pijakan dasar berpikir diperlukan sikap netral tanpa prasangka, agar tidak mempersempit data penalaran dan intuisi sebagai sarana penimbang dan penopang dalam memahaminya. Manusia harus memupuk keyakinan dan bhkatinya selama masa kehidupannya. Sebagaimana yang termuat dalam kitab Sarasamuscaya bahwa pergunakanlah dengan sebaik mungkin kesempatan menjelma menjadi manusia, kesempatan yang sulit untuk diperoleh, yang merupakan tangga menuju sorga, segala sesuatu yang menyebabkan agar tidak jatuh lagi, itulah hendaknya dilakukan.

Pada kenyatannya pada jaman Kaliyuga atau jaman seperti sekarang ini berbagai macam tanda tersirat dengan ketidakpastian dan penuh dengan perselisihan. Sebagaimana yang dinyatakan oleh Donder dan Wisarja (2011: 195) di dalam bukunya bahwa sudah menjadi suratan karma (yang harus terjadi) bahwa agama di era Kaliyuga mengalami ketidakberdayaan dalam menjadikan seluruh umat manusia sebagai makhluk paling mulia. Manusia sebagai makhluk yang paling mulia semestinya berprilaku yang mulia tetapi realitasnya sebagian besar manusia sangat jauh dari perilaku yang mulia. Keadaan umat manusia pada era ini disebabkan factor karena agama maupun keyakinan akan kebaikan dalam dirinya memudar. Dunia "kemanusiaan" dewasa ini benar-benar sangat mencemaskan, mengerikan hingga menimbulkan ketakutan yang luar biasa. Manusia kini mulai tidak bertanggung jawab akan perbuatannya, melalui ilmu pengetahuan yang dimiliki beberapa manusia menciptakan hal-hal yang dapat membuat keuntungan bagi dirinya sendiri tanpa memikirkan manusia lainnya. Berbagai jenis virus dan penyakit kini muncul dan membuat banyak korban jiwa yang berjatuhan. Virus yang telah menyebar keseluruh pelosok dunia membuat segala lini kehidupan mengalami perubahan yang signifikan, terkhusus pula dalam kehidupan beragama.

Kehidupan umat beragama dewasa ini mulai mengalami sebuah perubahan dalam mengamalkan praktik keagamanannya, dampak yang sangat signifikan yang didatangkan oleh virus yang dinamai covid-19. Virus ini telah menelan korban jiwa dalam jumlah yang sangat besar pada masyarakat di seluruh dunia. Sungguh sebuah kejadian yang luar biasa. Virus yang telah mewabah ke Indonesia dan Bali pada khususnya tentu menggerakkan pemerintah untuk mengeluarkan berbagai macam peraturan yang ketat, hal ini dikarenakan dampaknya dihampir semua aspek kehidupan manusia. Sector perekonomian melemah, begitu pula dalam dunia pendidikan sementara ditutup untuk pencegahan penularan yang lebih massif dan keselamatan 
bersama. Tidak hanya berdampak pada perekonomian dan dunia pendidikan, wabah ini juga membawa pengaruh pada aktivitas keagamaan, khususnya aktivitas keagamaan Hindu di Bali. Kebijakan yang dikeluarkan pemerintah dalam ritual maupun aktivitas keagamaan khususnya Hindu di Bali tentu menuai polemik pada masyarakat. Sebagian masyarakat menganggap bahwa kebijakan yang dikeluarkan merupakan wujud rendahnya keyakinan dan bhakti kepada Tuhan Yang Mahaesa, karena upacara yajna dilaksanakan merupakan wujud bhakti dan penolak bhaya atau musibah pada alam semesta.

Pemerintah selalu memiliki alasan yang jelas dalam setiap kebijakannya demi mencegah adanya penambahan korban jiwa akibat virus ini. Pemerintah mengarahkan masyarakat agar melakukan ritualnya secara pribadi di rumah masing-masing untuk membatasi jumlah kerumunan masyarakat. Semenjak dikelurkan kebijakan new normal selama pandemic covid-19 ini, pemerintah mengarahkan agar masyarakat mulai beradaptasi dengan kebiasaan dan perilaku baru yang membudayakan hidup bersih dan sehat, selalu menggunakan protocol kesehatan serta menjaga jarak saat melaksanakan ritual keagamaan. Wabah ini tidak hanya dipandang negatif juga dapat dipandang dari sisi positif yang menjadikan umat manusia perlahan mengubah cara hidupnya ke arah yang lebih baik, begitu pula terhadap cara mengamalkan ajaran agamanya. Untuk menjaga keselamatan dan kesehatan bersama, aktivitas keagamaan yang biasanya dilakukan secara marak dan meriah kini lebih menuju kepada kesadaran spiritual yang mendalam pada setiap individu.

\section{Pembahasan}

\section{Posisi Ritual dalam Kehidupan Beragama Hindu di Bali}

Isi uraian anak sub judul Pada dasarnya, ajaran agama Hindu terangkum ke dalam tiga bagian yang dikenal dengan "Tri Kerangka Dasar", dimana bagian satu dengan lainnya saling isi mengisi dan merupakan satu kesatuan yang bulat untuk dihayati dan diamalkan guna mencapai tujuan agama yang disebut dengan jagaditha atau kesejahteraan dan moksa atau kebebasan tertinggi. Tiga kerangka dasar itu adalah tattwa (filsafat agama), susila (etika) serta acara (praktek-praktek keagamaan). Dalam tattwa diuraikan intisari ajaran agama Hindu guna membimbing manusia untuk mencapai kesempurnaan hidup seutuhnya. Kemudian kerangka kedua yaitu susila (etika). Susila memegang peranan penting bagi tata kehidupan manusia sehari-hari. Realitanya hidup bagi seseorang dalam berkomunikasi dengan lingkungannya akan menentukan kadar budi pekerti yang bersangkutan. Manusia akan memperoleh simpati dari orang lain manakala dalam hidupnya selalu mencerminkan ketegasan sikap yang diwarnai oleh budi pekerti yang luhur dengan memegang teguh sendi-sendi kesusilaan, kebenaran serta 
Website Jurnal : https://ejournal.iahntp.ac.id/index.php/satya-widya/index

DOI: https://doi.org/10.33363/swjsa.v\%vi\%i.672

kejujuran. Kerangka ketiga yaitu acara yang meliputi pustaka suci, orang suci, hari suci, mantra, wariga atau hari baik serta yajna dalam berbagai bentuk dan kualitasnya.

Sangat jelas disini, Tri Kerangka Dasar agama Hindu antara satu dengan lainnya saling terikat dan berhubungan.Tattwa menjadi landasan teologis dari semua bentuk pelaksanaan ajaran agama Hindu. Susila menjadi landasan etis dari semua perilaku umat Hindu dalam hubungannya dengan Tuhan, sesama manusia, dan dengan alam lingkungannya. Sedangkan acara menjadi landasan prilaku keagamaan, tradisi, dan kebudayaan religius. Acara mengimplementasikan tattwa dan susila dalam wujud tata keberagamaan yang lebih riil dalam dimensi kebudayaan. Tanpa adanya acara, agama hanyalah seperangkat ajaran yang tidak akan nampak dalam dunia fenomenal. Secara sosio-antropologis, acara menjadi identitas suatu agama karena ia melembaga dalam sebuah sistem tindakan. Sebaliknya, tattwa (Ketuhanan) sangat abstrak sifatnya, demikian halnya dengan susila yang tidak hanya dibentuk oleh agama, melainkan juga oleh tradisi, adat, kebiasaan, tata nilai dan norma-norma sosial.

Acara agama merupakan bagian yang paling luar sehingga tampak dalam kegiatan hidup beragama. Ibarat melihat sebuah benda, maka bagian yang paling tampak adalah bagian yang paling luar luar yaitu kulitnya, sedangkan bagian dalamnya tidak tampak jelas. Guna dapat mengetahui benda tersebut dengan baik dan benar tidaklah cukup dilihat hanya dari sisi luar saja, ia haruslah juga dilihat bagian dalamnya yang merupakan inti atau jiwanya (Sukrawati, 2007: 13). Acara agama sekalipun menduduki posisi paling luar tidak berarti acara agama ini tidak begitu penting. Kedudukan acara agama ini juga tersurat dalam kitab Mānava Dharmaśāstra II.6 sebagai berikut:

\section{Vedo "khilo dharma mūlam smrtiśíle ca tadvidām ācāraścaiva sādhūnām àtmanastuștir eva ca}

Terjemahan:

Seluruh pustaka suci Veda merupakan sumber pertama dari dharma, kemudian adat istiadat, lalu tingkah laku yang terpuji dari orang-orang bijak yang mendalami ajaran suci Veda, juga tata cara kehidupan orang suci dan akhirnya kepuasan pribadi (Pudja, 2004: 31).

Sejalan dengan hal ini, apabila dilihat dari Tri Kerangka Dasar agama Hindu karena acara menduduki posisi yang terluar atau bagaikan kulitnya maka acara agama yang paling nampak dalam lingkungan masyarakat, yang dikenal pula dengan ritual atau sebuah ekspresi dari sebuah yajna. Yajna berarti korban suci yang dilaksanakan dengan tulus ikhlas atau 
lascarya. Tidak ada upacara yajna yang memiliki pengaruh optimal, jika dalam pelaksanaannya tidak didasari oleh rasa bhakti. Bhakti ini mensyaratkan adanya penyerahan diri secara total kepada yang Maha Kuasa, bhakti juga memerlukan tindakan tanpa sebuah harapan. Maka dari itu yajna yang baik senantiasa dilaksanakan dengan yasakertti yang baik pula. Menurut Puspa (2015: 229) dalam tulisannya menjelaskan bahwa menjalankan ajaran agamanya umat Hindu di Bali melalui jalan karma dan bhakti sehingga penekanannya dalam bentuk ritual dan simbolik dibandingkan dengan pemahaman dan pengetahuan serta filsafat agama. Dengan demikian agama Hindu oleh banyak pihak dipandang sebagai agama yang lebih menekankan pada bentuk ekspresif dibandingkan dengan agama dalam makna pengetahuan atau tattwa. Perihal bentuk-bentuk ekspresif ini menyitir pandangan Triguna (1994: 74), memang dikatakan tampak jelas dari rangkaian ritual yang disebutnya sebagai stages along life cyrcle maupun ritual-ritual agama yang ditujukan bagi kepentingan pemujaan dunia bawah maupun atas. Pada pelaksanaan ritual tersebut umumnya umat Hindu di Bali memakai simbol persembahan berupa upakara atau sarana upacara.

Ritual dalam agama Hindu disebut pula dengan upacara yajna, yang dalam kondisi apapun semestinya diusahakan untuk dilaksanakan karena merupakan sebuah swadharma atau kewajiban bagi umat Hindu. Namun yang perlu diperhatikan adalah dalam melaksanakan sebuah ritual ataupun aktivitas keagamaan perlu memahami tattwa yang tersirat di dalam ritual tersebut. Sebagaimana yang termuat dalam salah satu moto Sanskrit sebagai berikut:

\section{Ajarāmaravat prājnah vidyām \\ Artham cha chintayet, \\ Grihita iva kesheshu mrityunā \\ Dharmam ācharet}

Terjemahan:

When in search of knowledge or prosperity think that you would never have death or disease, and when worshipping God think that death's hand is in your hair.

Seorang bijaksana hendaknya berpikir tentang (pencarian) pengetahuan dan harta benda seakan-akan ia tidak akan menjadi tua atau mati, tetapi ia hendaknya melaksanakan kewajiban keagamaannya seakan-akan kematian telah mengintainya

Sloka senada juga termuat dalam pustaka suci Sārasamuccaya yang menyatakan bahwa dalam kehidupan manusia dituntut untuk melaksanakan swadharma-nya tanpa menunda-nunda lagi, sehingga posisi ritual bagi umat Hindu merupakan hal yang penting, selama bijak dan paham akan tujuan ritual yang dilaksanakan serta penuh dengan rasa bhakti dan keikhlasan. Sebagaimana yang tersirat pula di dalam petikan sloka berikut: 
Satya Widya : Jurnal Studi Agama Vol. 4 No. 12021

P-ISSN : 2623-0534

E-ISSN : 2655-1454

Website Jurnal : https://ejournal.iahntp.ac.id/index.php/satya-widya/index

DOI: https://doi.org/10.33363/swjsa.v\%vi\%i.672

aphalākāinkṣibhir yajño

vidhi-drișhto ya ijyate

yașhtavyam eveti manah

samādhāya sa sāttvikah

Terjemahan:

(Bhagavad Gītā, XVII.11)

Persembahan korban suci yang dilakukan oleh mereka yang sudah tidak menginginkan hasil dari persembahan korban suci yang dilakukan, persembahan korban suci yang dilakukan sesuai dengan aturan peraturan kitab-kitab suci, yang dilakukan setelah memantapkan dalam hati bahwa persembahan korban suci yang dilakukan adalah sebuah kewajiban yang harus dilakukan, persembahan korban suci seperti itu adalah korban suci dalam sifat kebaikan (Darmayasa, 2013: 673).

Pelaksanaan yajna dalam kaitannya dengan aktivitas ritual yang dilaksanakan umat Hindu khususnya di Bali, secara teologis dilaksanakan sebagai usaha dalam pencapaian keharmonisan. Keharmonisan yang dibentuk bukan hanya saja hubungan yang harmoni antara manusia dengan Tuhan saja, melainkan pula hubungan yang harmonis antara manusia dengan manusia, begitu pula manusia dengan lingkungan (alam). Sehingga ritual menduduki posisi yang penting dalam kehidupan umat Hindu di Bali. Sejalan dengan hal ini dijelaskan pula dalam pustaka suci Bhagavad Gītā III.14 sebagai berikut:

\section{annād bhavanti bhütāni \\ parjanyād anna-sambhavah \\ yajñād bhavati parjanyo \\ yajñah karma-samudbhavah}

\section{Terjemahan:}

Semua makhluk hidup dilahirkan dari makanan. Makanan dilahirkan dari hujan. Dan hujan turun karena pelaksanaan persembahan-persembahan suci yajna. Selanjutnya, persembahan suci yajna terlahir dari perbuatan (Darmayasa, 2013: 285).

Jelas disini terdapat resiprokal atau timbal balik, yang mana Tuhan sebagai pencipta alam semesta beserta isinya ini menganugerahkan kehidupan untuk disadari oleh umat manusia terkhusus umat Hindu untuk terus melakukan kerja (karma) untuk beryajna agar dapat saling memelihara, merawat dan menjaga satu sama lain, sehingga kehidupan ini dapat terus berlangsung baik di dunia ini maupun di kehidupan nanti. Jika tidak melakukan yajna dan hanya menikmati saja apa yang sudah dianugrahkan Tuhan, sesungguhnya orang itu adalah pencuri dan akan semakin banyak memakan dosanya sendiri. Oleh karena itu Hindu mengajarkan umatnya untuk saling menjaga, merawat atau memelihara melalui yajna, sebagai jalan untuk mencapai kesejahteraan (lahir) dan kebahagiaan tertinggi (batin).

\section{Makna Ritual dalam Agama Hindu}


Isi uraian Setiap umat manusia terkhusus umat Hindu di Bali hendaknya menyadari bahwa dalam hidup ini adalah sebuah kesempatan memperbaiki karma kehidupan sebelumnya agar menjadi makhluk yang utama, maka dari itu manusia harus mawas diri dan sadar akan adanya musuh yang terkadang mengantarkannya ke arah negatif yaitu kama, krodha, dan lobha. Ketiga sifat ini selalu mengikuti kehidupan manusia, dan perlu dipahami untuk mengendalikan ketiga hal tersebut dan ini menjadi tantangan tersendiri pada setiap umat manusia. Selain itu tantangan yang paling berat yang dihadapi oleh umat manusia adalah tantangan yang datang dalam dirinya sendiri, yakni sifat-sifat atau kecenderungan jahat yang merupakan sifat-sifat keraksasaan, kebalikan dari Daivisampat yang disebut Asurisampat (sifat-sifat Asura atau raksasa). Pertarungan antara sifat-sifat kedewataan dengan keraksasaaan inilah yang terus berlangsung dalam diri umat manusia yang sering mengejawantah dalam sikap dan prilaku sehari-hari. Pertarungan ini berlangsung terus tiada hentinya. Siapa yang berhasil memenangkan pertarungan dengan berpihak pada kebajikan atau dharma ialah yang sesungguhnya berhasil menegakkan dharma. Hanya dengan berpihak kepada dharma seseorang akan memperoleh keselamatan, kesejahtraan dan kebahagiaan lahir dan batin.

Pelaksanaan aktivitas keagamaan berupa pelaksanaan ritual yang sering dilaksanakan oleh umat Hindu di Bali pada khususnya, merupakan salah satu dari penerapan ajaran dharma itu sendiri. Upacara Yajna ataupun aktivitas ritual adalah suatu karya suci yang dilaksanakan dengan penuh rasa ikhlas, karena getaran jiwa dalam kehidupan ini berdasar atas dharma. Sesuai ajaran sastra suci Hindu, yajna dapat diartikan sebagai memuja, menghormati, berkorban, mengabdi, berbuat baik (kebajikan), pemberian, dan penyerahan dengan penuh ketulusikhlasan. Yajna sendiri mengandung nilai-nilai suci berupa rasa bakti dan memuja (menghormati) Ida Sang Hyang Widhi Wasa, Dewa, leluhur, bangsa dan negara, serta kemanusiaan. Begitu pula dalam pelaksanaannya disesuaikan dengan kemampuan masingmasing menurut tempat (desa), waktu (kala), dan keadaan (patra). Yajna dalam kehidupan umat Hindu di Bali nampak dalam segala aktivitas agama atau ritual yang dilaksanakan sehari-hari maupun pada waktu tertentu, dan diyakini membawa pengaruh besar dalam kehidupan manusia. Sebagaimana dalam terjemahan sloka Mahanarayana Upanisad XXII.1 yang menjelaskan mengenai dharma sebagai prinsip dasar kehidupan, bahwa dharma adalah prinsip dasar dari segala sesuatu yang bergerak dan yang tidak bergerak di alam semesta ini. Seluruh dunia dan segenap umat manusia hendaknya selalu bergairah mengikuti ajaran dharma. Yang mengikuti ajaran dharma terbebas dari segala dosa. Segala sesuatunya akan berjalan 
Satya Widya : Jurnal Studi Agama Vol. 4 No. 12021

P-ISSN : 2623-0534

E-ISSN : 2655-1454

Website Jurnal : https://ejournal.iahntp.ac.id/index.php/satya-widya/index

DOI: https://doi.org/10.33363/swjsa.v\%vi\%i.672

mantap bila di jalan dharma. Untuk itu patutlah dharma itu disebut ajaran yang tertinggi.

Demikian pula termuat di dalam pustaka suci Mānava Dharmaśāstra VIII.15 sebagai berikut :

\section{Dharma eva hato hanti \\ Dharmo rakșati rakșitah \\ Tasmād dharmo na hantavyo \\ Mà no dharmo hatovadhït}

Terjemahan :

Keadilan yang dilanggar menghancurkan keadilan yang dipelihara akan menjaminnya; oleh karena itu keadilan jangan dilanggar, melanggar keadilan akan menghancurkan diri kita (Pudja, 2004: 344).

Berdasar kutipan sloka di atas dapat dipahami bahwa ajaran agama Hindu menekankan betapa pentingnya melaksanakan dharma untuk mewujudkan kesejahteraan dan kebahagiaan baik sebagai mahluk individu maupun sosial dalam hubungannya sebagai umat beragama maupun sebagai warga negara. Umat Hindu sebagai makhluk individu perlu menyadari bahwa kelahirannya ke dunia membawa tiga hutang yang semestinya dibayar selama menjalani kehidupannya, yang dikenal dengan Tri Rna. Tri Rna ini sendiri merupakan pelaksanaan dari sebuah yajna atau ritual itu sendiri, adapun bagiannya yaitu hutang kepada Tuhan (Dewa Rna); hutang kepada Para Maharsi atau guru suci (Rsi Rna); serta hutang kepada orang tua dan leluhur (Pitra Rna). Ketiga hutang ini sesungguhnya terkait dengan eksistensi manusia di dunia ini. Keberadaan manusia di dunia ini dan keberlangsungannya (survival) merupakan karya agung dari Tuhan. Beliau menciptakan alam semesta beserta isinya melalui sebuah yajna, menjaga dengan yajna, dan mengembalikan semua yang ada dengan yajna pula.

Setelah Tuhan menciptakan alam semesta, termasuk di dalamnya manusia, diturunkanlah pengetahuan suci Veda yang menuntun manusia agar hidup serasi, selaras, dan seimbang dengan alam karena kaharmonisan inilah yang akan membuat manusia bertahan pada kehidupannya. Turunnya wahyu Veda tidak dapat dipisahkan dari peranan para Maharsi yang telah mengabdikan dirinya untuk melaksanakan tapa, brata, yoga, dan samadhi. Melalui proses inilah para Maharsi menerima wahyu suci Veda dan kemudian mengajarkannya kepada seluruh umat manusia. Selanjutnya, ajaran Veda mengalir dan diterima oleh generasi sekarang karena adanya regenerasi dari para leluhur terdahulu. Proses siklus bahwa setiap yang lahir akan mati, kemudian terlahir kembali menjadi pedoman bahwa setiap generasi hilang dan muncul generasi baru. Oleh karena itu kitab Veda yang masih diterima hingga saat ini dan juga generasi yang akan datang merupakan keberlanjutan kehidupan manusia dari leluhur-leluhur terdahulu yang 
dari generasi ke generasi berikutnya melahirkan keturunan yang berkualitas demi keberlanjutan pengetahuan suci Veda dan keberlangsungan eksistensi manusia itu sendiri tetap terjaga. Demikian besar hutang manusia terhadap Tuhan, para Maharsi, dan para leluhur karena merekalah eksistensi manusia di dunia ini terpelihara. Atas dasar inilah sebuah ritual suci untuk membayar ketiga hutang kepada Tuhan, leluhur dan rsi (guru) wajib untuk dibayarkan. Termuat makna bhakti di dalam pelaksanaan ritual tersebut, bawasannya melalui pelaksanaan ritual suci manusia dapat melakukan komunikasi dengan para Dewa, dan atas yajna tersebut para Dewa akan memberikan anugerah kepada manusia. Inilah puncak dari konsep bhakti, yaitu manusa bhakti dewa asih (manusia beryajna untuk mendapatkan kasih Tuhan). Sebuah ritual yang suci juga merupakan aktivitas yajna yang dapat memurnikan jiwa seseorang. Sebagaimana yang termuat dalam pustaka suci Bhagavad Gītā XVIII.5 sebagai berikut :

yajña-dāna-tapah-karma

na tyājyam kāryam eva tat

yajño dānam tapaśh chaiva

pāvanāni manīṣhiṇām

Terjemahan :

Pelaksanaan-pelaksanaan korban suci, kedermawanan dan pertapaan tidak patut ditinggalkan, sebaliknya semua kegiatan mulia itu harus dilakukan karena pelaksanaanpelaksanaan korban suci, kedermawanan dan juga pertapaan akan menyucikan bahkan orang-orang suci terpelajar (Darmayasa, 2013: 696).

Sejalan dengan hal di atas dalam Mānava Dharmaśāstra III.72 menjelaskan akan pentingnya melaksanakan sebuah ritual agama sebagai berikut:

\section{Devatātithi bhrtyānām \\ pitṛnāmātmanaśca yạ \\ na nirvapati pancānam \\ ucchvasanna sa jīvati}

Terjemahan :

Tetapi ia yang tidak memberikan persembahan kepada kelima macam tadi yaitu kepada para Dewa, para tamunya, mereka yang harus pelihara, para leluhur dan ia sendiri, pada hakekatnya tidak hidup walaupun bernafas (Pudja, 2004: 109).

Sebuah pengorbanan ataupun pelaksanaan kegiatan keagamaan dalam keadaan apapun penting untuk dilaksanakan, karena manusia wajib mensyukuri kehidupan dan memiliki tugas untuk mengharmoniskan kehidupan semesta ini. Pemujaan, persembahan atau pengorbanan ditujukan kepada Tuhan Yang maha Esa, para dewata, leluhur dan bahkan kepada sesama manusia dan mahluk hidup lainnya yang merupakan ciptaan-Nya, menyiratkan bahwa manusia ikut aktif dalam memutar roda yajna. Sebagaimana dalam pustaka suci Bhagavad Gìtā III.14 menjelaskan bahwa "dari makanan mahluk hidup menjadi ada, dari hujan lahirlah makanan, 
Satya Widya : Jurnal Studi Agama Vol. 4 No. 12021

P-ISSN : 2623-0534

E-ISSN : 2655-1454

Website Jurnal : https://ejournal.iahntp.ac.id/index.php/satya-widya/index

DOI: https://doi.org/10.33363/swjsa.v\%vi\%i.672

dari yajña muncul hujan dan yajña lahir dari kerja”. Dengan demikain setiap orang tidak akan dapat menghindarkan dirinya untuk tidak melakukan yajña. Yang tidak kalah pentingnya sebuah ritual suci merupakan cerminan dari konsep sraddha sebagai umat Hindu, sebagaimana yang diketahui bahwa sraddha tanpa bhakti tidaklah cukup. Hal ini ditegaskan pula dalam pustaka suci Bhagavad Gītā VII.22 sebagai berikut :

\section{sa tayā śhraddhayā yuktas \\ tasyārädhanam ìhate \\ labhate cha tatah kāmān \\ mayaiva vihitān hi tān}

Terjemahan:

Orang yang sudah dimantapkan keyakinannya (kepada para Dewa tersebut oleh-Ku), maka ia melakukan pemujaan sesuai dengan keinginannya, dan keinginankeinginannya itu menjadi terpenuhi. Tetapi, sesungguhnya Aku-lah yang mengabulkan keinginan-keinginannya itu (Darmayasa, 2013: 415).

Hal ini menunjukkan betapa toleransi atau penghargaan terhadap keimanan atau keyakinan seseorang, sebab pada hakekatnya ke-bhakti-an itu akan terkabul oleh Tuhan Yang Maha Esa, agama Hindu memberikan kebebasan kepada umat-Nya untuk menempuh berbagai jalan yang dirasa cocok oleh pribadi yang bersangkutan. Adapun jalan tersebut dikenal dengan Catur Marga yang terdiri dari Bhakti Marga (jalan bhakti), Karma Marga (jalan perbuatan), Jnana Marga (Jalan pengetahuan), dan Yoga Marga (jalan spiritual/ meditasi). Diantara empat jalan ini, yang paling umum dan banyak dijalankan adalah bhakti yoga karena jalan yang paling mudah dijalankan oleh umat Hindu umumnya. Dari berbagai bentuk pelaksanaan bhakti marga, maka pelaksanaan tri sandhya, sembahyang, dan berdoa merupakan jalan yang sederhana dan mudah dilaksanakan oleh setiap orang, di samping tentunya membuat berbagai upacara persembahan, pembangunan tempat pemujaan dan berbagai symbol keagamaan yang pada intinya adalah untuk meningkatkan sradha dan bhakti kepada Tuhan Yang Maha Esa (Suryani, 2014: 9).

\section{Tantangan dan Tatanan Ritual Agama Hindu di Masa Pandemi}

Pandemi covid-19 yang telah melanda seluruh dunia termasuk Pulau Bali tidak hanya merenggut ribuan nyawa tetapi juga mengubah tata cara kehidupan manusia di seluruh dunia, mulai dari proses interaksi sesama maupun proses berhubungan dengan Tuhan. Sebagian orang memutuskan untuk mengurung diri di rumah, menghindari tempat keramaian, dan menunda perjalanan ke tempat lain, adapula yang masuh melakukan aktifitas seperti biasanya karena tuntutan ekonomi dan lain-lain. Selama pandemi, agama telah menunjukkan peran-peran 
pentingnya dalam membantu memotong rantai penyebaran virus ini. PHDI Provinsi Bali dan Majelis Desa Adat Provinsi Bali mengeluarkan ketentuan pelaksanaan upacara panca yajna selama pandemi di Bali. Adapun beberapa aturan yang keluarkan yaitu :

1. Semua upacara panca yajna yang bersifat ngawangun (direncanakan), agar ditunda sampai batas waktu yang ditentukan

2. Upacara panca yajna selain yang bersifat ngawangun (direncanakan) dapat dilaksanakan dengan peserta terbatas

3. Dalam setiap pelaksanaan upacara panca yajna sebagaimana yang dimaksud agar mengikuti prosedur tetap penanggulangan covid-19.

Secara keseluruhan kehidupan di dunia berubah total, semenjak dikeluarkan kebijakan mengenai "new normal" segala lini kehidupan harus membiasakan diri untuk merubah kehidupannya menjadi hidup yang memperhatikan kesehatan, begitu pula dalam menjalankan aktivitas keagamaan. Menurut Widana (2018: 4) ketika umat Hindu melaksanakan kewajiban bhakti melalui ritual, telah membalikkan konsep ideal mayajna ke dalam konteks sajian material-fisikal. Sehingga aktivitas ritual umat Hindu kekinian lebih tampak sebagai media eksistensi dan aktualisasi diri melalui perhelatan yajna di panggung ritual, dengan melibatkan banyak pelaku, baik yang murni berdasar konsep parabhakti atau sebaliknya lebih banyak digerakkan semangat aparabhakti (pamer dan pamrih). Kutipan di atas memberikan gambaran bahwa kondisi saat ini yang membawa tantangan tersendiri bagi umat Hindu dalam melaksanakan aktivitas agama akibat pembatasan aktivitas yang tidak boleh melibatkan banyak orang. Oleh karena itu sudah saatnya bentuk-bentuk konteks mayajna yang diterapkan khusus dimasa pandemic ini ditata bersama melalui pelaksanaan kebijakan/aturan yang disepakati bersama.

Masyarakat perlu melakukan perubahan social dalam segala aktivitasnya termasuk aktivitas keagamaannya, namun tidak semua orang memiliki kesadaran akan pentingnya perubahan demi kesehatan dan keselamatan banyak umat. Sebagian masyarakat awalnya menentang akan pembatasan aktivitas keagamaan ini, karena mereka keyakinan bahwa ritual yang dilaksanakan untuk menetralisir virus yang dianggap baya ini. Dalam kondisi pandemic seperti saat ini, masyarakat juga perlu sebuah pengendalian diri untuk memahami bahwa ritual keagamaan dapat dilaksanakan pada rumah masing-masing dan dalam wujud merealisasikan bhakti kepada Tuhan, dapat dilaksanakan secara sederhana. Masyarakat kini perlu memahami dan lelih menuju ke arah tattwa dalam rangkaian pelaksanaan ritual yang dituju. Pengendalian 
Satya Widya : Jurnal Studi Agama Vol. 4 No. 12021

P-ISSN : 2623-0534

E-ISSN : 2655-1454

Website Jurnal : https://ejournal.iahntp.ac.id/index.php/satya-widya/index

DOI: https://doi.org/10.33363/swjsa.v\%vi\%i.672

pikiran menjadi kunci utama dalam menghadapi tantangan kehidupan aktivitas keagamaan

pada masa covid-19 ini, sebagaimana yang termuat dalam pustaka suci Sārasamuccaya 60

berikut:

Apan ikang manah ngaranya, ya ika witning indriya, maprawrtti ta ya ring śubhāśubhakarma, matangnyan ikang manah juga prihen kahrtanya sakareng.

Terjemahan:

Sebab yang disebut pikiran itu, adalah sumbernya nafsu, ialah yang menggerakkan perbuatan yang baik ataupun yang buruk; oleh karena itu, pikiranlah yang segera patut diusahakan pengekangannya/ pengendaliannya (Kadjeng, dkk. 1999: 67).

Tak satupun masyarakat dan kebudayaan di dunia hidup statis tanpa mengalami proses perubahan. Menurut Triguna (2011: 35) manusia senantiasa mengalami proses diferensiasi sosio-struktural dan suatu generalisasi nilai, norma, dan makna yang menyertainya. Dalam hubungan kebudayaan, pergeseran itu akan sangat memberi kontribusi terhadap pengetahuan sebagai suatu budaya. Setiap orang yang telah tersentuh sistem pengetahuannya akan mencoba memberi makna dan arti "baru" bagi tatanan yang ada sebelumnya, tidak terkecuali hal-hal yang bersifat normative. Manusia berusaha pula menyesuaikan lingkungan dan keinginan, dan tujuan mereka. Mengingat lingkungan yang diadaptasi manusia terus berubah, maka di dalam upaya pengadaptasian itu, manusia akan terus mengikuti, mengamati dan menginterpretasi berbagai gejala dan perubahan yang terjadi di dalam lingkungan mereka.

Umat Hindu pada umumnya menaruh perhatian yang sangat besar pada pelaksanaan ritual sebagai kegiatan yang sudah mendarah daging. Ritual keagamaan dalam pelaksanaannya memberikan peluang besar bagi umat Hindu dimanapun mereka berada untuk beraktivitas dan berkreasi sesuai dengan adat budaya yang paling mereka hayati sehingga yajña merupakan salah satu aspek ajaran agama Hindu menyatu dengan adat budaya setempat. Pelaksanaan yajña (ritual) yang tampak meriah dan semarak hanya dalam penampilannya saja tentulah belum sempurna. Kesemarakan dan kemeriahan itu haruslah disertai dengan kedalaman akan makna yang terkandung di dalamnya, sehingga kesemarakan dan kemeriahan itu tidaklah kosong atau hampa tanpa makna, karena tidak menutup kemungkinan juga bahwa masyarakat kita dalam melaksanakan kegiatan keagamaan itu hanya ikut-ikutan saja yang di Bali disebut gugon tawon. Artinya bahwa mereka melaksanakan prosesi ritual itu hanya karena ikut-ikutan saja meniru dari apa yang dilaksanakan sebelumnya atau oleh orang lain di sekelilingnya tanpa memahami apa makna dari yang mereka lakukan itu. Di satu sisi pelaksanaan atas dasar gugon tawon adalah positif yaitu dengan dasar keyakinan yang diterima secara turun temurun yang 
bersifat tradisional itu menyebabkan tradisi itu sekaligus umat pendukungnya mampu bertahan hingga kini.

Menurut Puspa (2015) telah terjadi pergeseran dalam aktivitas ritual umat Hindu, dengan menyatakan bahwa dewasa ini, yang berkembang adalah berbagai bentuk realitasrealitas ritual artifisial, dan berbagai budaya materi serta gaya hidup yang menyertainya yang justru bertentangan dengan hakikat ritual itu sendiri sebagai ruang penyucian jiwa. Kegiatan ritual keagamaan, sebaliknya telah berkembang menjadi ruang pemanjaan jiwa, lewat berbagai bentuk tanda (sign), citra (image), gaya (style), ilusi, prestise, gaya hidup (lifestyle), dan pesona objek (fetishim) yang ditawarkan di dalamnya. Pengembangbiakan budaya komoditi, budaya pencitraan, dan gaya hidup di dalam masyarakat konsumer atau masyarakat skizofrenik, telah menggiring kegiatan ritual keagamaan ke dalam jagat komoditas atau komodifikasi ritual yang didorong semangat euphoria. Hal ini disinyalir oleh Puja (2015: 546) yang menerangkan, bahwa euforia ritual yang terjadi di Bali disebabkan oleh rendahnya pemahaman tattwa agama atau masyarakat Bali yang masih banyak belum memahami ajaran agama Hindu secara baik.

Menurut Donder (2013: 513-515) "Ritual is a tool and not a final goal of human being. The final goal of human life is self-realisation, that is, unity with God. Ritual is an important part of religion, especially in the Hindu religion. Because of the rituals' importance, the rituals have survived for so long, but many people still misunderstand the Hindu rituals; and this misunderstanding is due to their ignorance to the rituals, they never wanted to know properly about the rituals. Terjemahannya: "Ritual adalah alat dan bukan tujuan akhir manusia. Tujuan akhir kehidupan manusia adalah realisasi diri, yaitu persatuan dengan Tuhan. Ritual adalah bagian penting dari agama, terutama dalam agama Hindu. Karena pentingnya ritual tersebut, ritual tersebut bertahan begitu lama, namun banyak orang masih salah mengerti ritual Hindu; dan kesalahpahaman ini disebabkan oleh ketidaktahuan mereka terhadap ritual, mereka tidak pernah ingin mengetahui dengan benar tentang ritual tersebut. Maswinara (1996: 25) di dalam bukunya juga menjelaskan bahwa ritual yang sesungguhnya adalah karya nyata sebagai tugas kewajiban manusia secara langsung untuk turun tangan ikut bertanggung jawab terhadap kelestarian alam, yang secara timbal balik nantinya alam juga akan memberikan kesejahteraan kepada manusia secara otomatis. Lambang-lambang yang digambarkan dalam upacara ritual itu sendiri sebenanya memberikan arah yang jelas kepada manusia, bagaimana dan kemana arah tujuan karya nyata yang dimaksudkan oleh ritual itu. Berdasarkan hal tersebut, menjaga keselamatan diri sendiri dan bersama juga merupakan bentuk ritual atau yajna yang dapat diterapkan di dalam kondisi pandemi seperti sekarang ini. Ditegaskan oleh Radhakrishnan 
Website Jurnal : https://ejournal.iahntp.ac.id/index.php/satya-widya/index

DOI: https://doi.org/10.33363/swjsa.v\%vi\%i.672

(2003: 55) yang menyatakan bahwa hakikat agama tidak terletak pada dogma-dogma dan ritusritus serta upacara-upacara menjemukan, tetapi dalam kebijaksanaan-kebijaksanaan paling dalam dari segala zaman, sanatana dharma, yang merupakan satu-satunya pedoman, bukan semata-mata menyangkut kebenaran, melainkan pandangan-pandangan atau pemahaman terhadap kebenaran yang telah diyakini manusia.

\section{Simpulan}

Kondisi pandemi seperti sekarang ini membawa banyak perubahan ke dalam kehidupan manusia, termasuk ke dalam kehidupan umat beragama. Agama Hindu sebagai agama yang tidak dapat dilepaskan dari pelaksanaan ritual-ritual keagamaan (yajna), di dalam kondisi seperti saat ini perlu memahami dan memaknai kembali segala aktivitas ritual yang dilaksanakan. Keyakinan bahwa ritual yang dilaksanakan untuk menetralisir virus yang dianggap baya ini sangat diperlukan sebagai bentuk sraddha dan bhakti umat kepada Tuhan. Dalam kondisi pandemic seperti saat ini, masyarakat juga perlu dikuatkan dengan pengendalian diri untuk memahami bahwa ritual keagamaan dapat dilaksanakan secara sederhana tanpa harus melibatkan banyak orang. Menjaga keselamatan diri sendiri dan bersama juga merupakan bentuk ritual atau yajna yang dapat diterapkan di dalam kondisi pandemi seperti sekarang ini.

\section{Daftar Pustaka}

Donder, I Ketut., Wisarja, I Ketut. (2011). Teologi Sosial Persoalan Agama dan Kemanusiaan Perspektif Hindu. Surabaya: Paramita.

Donder, I Ketut. (2013). Logical Interpretation of Some Performing Hindu Rituals. Disertasi. Kolkata India: Rabhindra Bharati University.

Kajeng, I Nyoman., dkk. (1999). Sārasamuccaya. Surabaya: Paramita.

Maswinara, I Wayan. (1996). Konsep Panca Sraddha. Surabaya: Paramita.

Pudja, G. (2004). Mānava Dharmaśāstra. Surabaya: Paramita.

Tim Peneliti WHP/WHC dan I Gede Suwantana (Ed). (2015). Hambatan dan Keluhan Umat Hindu Dalam Melaksanakan Panca Yadnya. Artikel dalam Buku Konsep Dan Praktik Agama Hindu Di Bali/ Surabaya: Paramita

Radhakrishnan, S. (2003). Religion and Society. Denpasar: Widya Guna.

Sukrawati, Ni Wayan. (2007). Kaedah Beryajna, Orang-Orang Suci dan Tempat Suci (Acara 1). Surabaya: Paramita.

Suryani, I Gusti Ayu Putu, dkk. (2014). Pendidikan Agama Hindu di Perguruan Tinggi. Denpasar: Udayana University Press. 
Triguna, Ida Bagus Gde Yudha dan I Gede Pitana (Ed.). (1994). Pergeseran dalam Pelaksanaan Agama: Menuju Tattwa.Dalam Dinamika dan Kebudayaan Bali. Denpasar: Bali Post.

Triguna, Ida Bagus Gde Yudha. (2011). Strategi Hindu. Jakarta: Pustaka Jurnal Keluarga.

Widana, I Gusti Ketut. (2018). Aktivitas Ritual Umat Hindu, Antara Reproduksi Identitas Dan Religiositas (Perspektif Teologi Kontemporer). Denpasar: Pascasarjana Unhi Denpasar. 